\title{
PERKEMBANGAN CORAK PENAFSIRAN AL-QUR'AN DARI PERIODE KLASIK SAMPAI MODERN
}

\section{The Development of The Qualification of The Quran Exegesis from Classic to Modern Period}

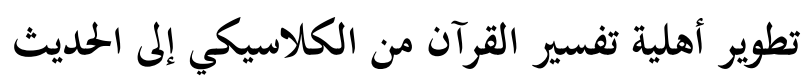

\author{
Muhamad Ibtissam Han', Topikurohman² \\ ${ }^{1}$ Institut PTIQ Jakarta, Indonesia \\ 'mibtissamhan@ptiq.ac.id \\ ${ }^{2}$ Institut PTIQ Jakarta, Indonesia \\ ²topikurohman@ptiq.ac.id
}

\begin{abstract}
Abstrak:
Artikel ini akan memaparkan perkembangan corak tafsir al-Qur'an dari periode klasik hingga periode modern. Penulis menggunakan model penelitian literatur (library research) dengan menelusuri buku-buku mengenai tafsir dari para ulama maupun komentar-komentar cendikiawan. Secara garis besar periode klasik banyak mengadopsi model penafsiran berbasis tradisi dan banyak menggunakan sumber-sumber israiliyat pun menekankan pada aspek kebahasaan. Sedangkan pada periode modern muncul penolakan terhadap tradisi lama mulai dari penggunaan tradisi israiliyat, otoritas nabi, kebahasaan sampai dengan pengaruh tradisi berfikir positivisme ala Barat yang mewarnai berbagai corak penafsiran pada periode modern dengan banyak menolak konsep-konsep mistis dan primitif, mereka juga merasionalisasikan gagasan-gagasan agama yang bersifat droktinal.
\end{abstract}

Kata Kunci: Corak Tafsir al-Qur’an, Periode Klasik, Periode Modern.

\begin{abstract}
:
This article will explain the development of the style of interpretation of the Koran from the classical period to the modern period. The authors use the literature research model (literature study) by reading books on interpretations from scholars and commentaries of scholars. Broadly speaking, the Classical period has many agreed-upon models of interpretation based on tradition and many uses of Islamic sources also support the linguistic aspect. While in the modern period emerged against the Old traditions ranging from the use of israiliyat tradition, the authority of the prophet, linguistic to the combination of the tradition of Western positivism thinking that illustrates various interpretations in the modern period with the exchange of mystical concepts and primitive concepts, also helped realize the discussions that support religion drocal.
\end{abstract}

Keywords: Al-Qur'an style of Exegesis, Classical period, Modern period 


$$
\begin{aligned}
& \text { الملتخص: } \\
& \text { سيصف هذا المقال تطور تفسير القرآن من الفترة الكلاسيكية إلى العصر الحديث. نستخدم نموذج البحث الأدبي } \\
& \text { من خلال تصفح كتب تفسيرات العلماء وتعليقات العلماء. بشكل عام، اعتمدت الفترة الكلاسيكية الكثير من } \\
& \text { نماذج التفسير المبنية على التقاليد واستخدمت الكثير من المصادر الإسرائيلية، مع التركيز على الجانب اللغوي. في } \\
& \text { هذه الأثناء، في العصر الحديث، كان هناك رفض للتقاليد القديمة بدءًا من استخدام التقليد الإسرائيلي، وسلطة } \\
& \text { النبي، واللغة إلى تأثير تقليد التفكير الوضعي على النمط الغربي الذي صبغ تفسيرات مختلفة في العصر الحديث. من } \\
& \text { خلال رفض العديد من المفاهيم الصوفية والبدائية، قاموا أيضًا بترشيد أفكار العصر الحديث الأفكار الدينية المتدنية. } \\
& \text { الكلمات المفتاحية: أنماط تفسير القرآن، العصر الكلاسيكي، العصر الحديث. }
\end{aligned}
$$

\section{Pendahuluan}

Tafsir al-Qur'an adalah salah satu disiplin ilmu paling penting dalam studi-studi Islam. Hal ini dikarenakan posisi al-Qur'an sebagai teks suci yang sangat sentral dalam studi Islam. Menurut Talal Asad bahkan sesuatu tindakan, gagasan, teks dapat dikatakan sebagai Islam hanya ketika bersandar kepada al-Qur'an dan hadis. ${ }^{1}$ Namun meski demikian, al-Qur'an sejatinya adalah teks, sama halnya dengan teks pada umumnya, yang membutuhkan pikiran yang aktif untuk mengeksplorasi maknanya dan menerapkan petunjuk yang ada di dalamnya dalam keadaan yang terus berubah. Dan sebagai teks ia bisu dan membutuhkan penafsiran agar ia relevan dengan kehidupan. ${ }^{2}$ Sejalan dengan itu Isman Gusmian mengungkapkan bahwa al-Qur'an hanyalah mushaf yang tidak bermakna tanpa dialektika antara manusia yang membacanya degan teks alQur'an itu sendiri. ${ }^{3}$

Lalu muncul pertanyaan, siapa yang berhak untuk menafsirkan al-Qur'an? Jawabannya tentu saja Nabi Muhammad saw. Sebagai sosok utama penerima wahyu. Maka ketika ada persoalan di kalangan sahabat, para sahabat akan menanyakannya langsung kepada Nabi. Bahkan peran nabi dalam tafsir al-Qur'an dinyatakan dalam alQur'an itu sendiri yakni pada QS An Nahl [16]:44.

Namun demikian, hadis Nabi (praktik standar, yaitu kata-kata dan tindakannya) dan al-Qur'an segera membentuk hubungan timbal balik eksegetis. Dalam hal penafsiran al-Qur'an, hubungan antara al-Qur'an dan hadis ini telah menjadi masalah saling ketergantungan. Dalam pandangan para cendekiawan Muslim arus utama dan non-arus utama, al-Quran lah yang membutuhkan hadis dan bukan sebaliknya.

${ }^{1}$ Talal Asad, "The Idea of an Anthropology of Islam," Qui Parle 17, no. 2 (2009): 1-30, https://doi.org/10.5250/quiparle.17.2.1; Sunarwoto, ed., Islam: Antara Teks, Kuasa dan Identitas (Yogyakarta: Arti Bumi Intaran, 2018), 4.

${ }^{2}$ Gudrun Krämer dan Sabine Schmidtke, ed., Speaking for Islam: religious authorities in Muslim societies, Social, economic and political studies of the Middle East and Asia, v. 100 (Leiden ; Boston: Brill, 2006), 3-4.

${ }^{3}$ Islah Gusmian, Khazanah tafsir Indonesia: dari hermeneutika hingga ideologi, Cetakan I (Yogyakarta: Penerbit \& distribusi, LKiS Yogyakarta, 2013), 27.

at-ðurhan: Kajian Ilmu dan Pengembangan Budaya Al-Qur'an, Vol. 20, No. 2, Desember 2020: 263-280 | 264 
Meskipun hadis menjelaskan al-Qur'an, itu adalah al-Qur'an, dan bukan hadis, yang dapat mencabut beberapa ayah Al-Qur'an. ${ }^{4}$ Dan yang tidak kalah penting, tidak banyak yang diketahui seberapa banyak sebenarnya yang dijelaskan oleh Nabi, sebagai seorang penafsir, kepada para sahabat karena sedikit dari penafsiran Al-Qur'an Nabi sendiri yang dicatat karena ia menggambarkan konsep dan perintah Al-Qur'an dengan tindakannya. ${ }^{5}$

Namun ketika Nabi wafat, proses penafsiran tidak berhenti sampai di situ, terutama ketika muncul permasalahan yang tidak ada ketika Nabi masih hidup. Maka para sahabat ${ }^{6}$ berupaya menafsirakn al-Qur'an dengan merujuk riwayat-riwayat yang disandarkan kepada Nabi, atau yang juga dikenal dengan istilah tafsir bil ma'tsur atau tafsir bir riwayah. Pada saat ini pula komunitas Muslim telah menyaksikan periode gejolak teologis dan politik yang intens. Fitnah (perang saudara) pada $41 \mathrm{H} / 662 \mathrm{M}$ dipicu oleh pembunuhan kalifah ketiga Usman bin Affan pada $35 \mathrm{H} / 656 \mathrm{M}$. Ini adalah titik penting dalam sejarah Islam, yang bersama dengan evolusi pendapat hipotetis berdasarkan pemikiran spekulatif telah menyebabkan perselisihan politis dan teologis, munculnya penafsiran non-arus utama, pemalsuan hadis, dan pandangan eksegetis yang dibuat-buat yang secara keliru dianggap berasal dari ikon sahabat. Karena itu, tafsir al-Quran telah menjadi kendaraan yang melaluinya pandangan-pandangan dogmatis dan politis disalurkan. Dengan maraknya eksegesis penalaran pribadi, polemik eksegetis juga berkembang. ${ }^{7}$

Pada periode tabiin, kebutuhan akan penafsiran meningkat. Mereka adalah kelompok yang lebih heterogen karena terdiri dari mereka yang memang keturunan dari para sahabat Nabi, juga para mualaf baru. Pada saat itu, di beberapa kota seperti Madinah, Mekah, Damaskus dan Irak, mulai dikembangkan proto-tradisi penafsiran lokal di bawah bimbingan sahabat mereka masing-masing (Ibn 'Abbas, Ubayy ibn Ka'b, dan Ibn Mas 'ud). ${ }^{8}$ Perlu dicatat di sini ada perdebatan tentang keberadaan literatur eksegetikal pada abad pertama hijriah, karena tafsir al-Qur'an paling awal (pada masa Nabi dan para sahabat) utamanya bersifat lisan, dan juga bergantung pada transmisi lisan dan penafsiran tertulis baru dikembangkan kemudian, yakni pada abad kedua hijriah. ${ }^{9}$

Perlu dicatat bahwa secara garis besar tafsir al-Qur'an terbagi menjadi dua yaitu tafsir bil-ma'thūr (penafsiran berbasis tradisi) dan tafsir bil-ra'yi (penafsiran berbasis alasan) atau sarjana lain menyebutnya sebagai tafsir tekstual dan tafsir kontekstual. Secara sederhana Tafsir berdasarkan tradisi menekankan penafsiran al-Qur'an dengan al-Qur'an, dengan hadis Nabi, atau dengan pendapat Muslim awal (sahabat atau tabiin), serta membatasi ruang lingkup untuk penalaran independen dalam pemahaman dan interpretasi teks al-Qur'an. Sedangkan penafsiran berdasarkan alasan tidak hanya

\footnotetext{
${ }^{4}$ Hussein Abdul-Raof, Schools of Qur'anic Exegesis: Genesis and Development (London; New York: Routledge, 2013).

${ }^{5}$ Hakan Çoruh, Modern Interpretation of the Qur'an: The Contribution of Bediuzzaman Said Nursi (Cham: Springer International Publishing, 2019), 8, https://doi.org/10.1007/978-3-030-15349-6.

${ }^{6}$ Hanya beberapa sahabat Nabi yang tercatat berkontribusi langsung pada penafsiran Al-Qur'an. Ini termasuk empat khalifah pertama kemudian disusul Ibn Abbas (w. 687 M), Ubayy ibn Ka'b (w. 656 M) dan 'Abd Allāh ibn Mas'ūd (w. 653 M).

${ }^{7}$ Abdul-Raof, Schools of Qur'anic Exegesis.

${ }^{8}$ Abdullah Saeed, The Qur'an: An Introduction (New York: Routledge, 2009), 195.

${ }^{9}$ Çoruh, Modern Interpretation of the Qur'an, 8. 265 | at-هurhan: Kajian Ilmu dan Pengembangan Budaya Al-Qur'an, Vol. 20, No. 2, Desember 2020: $263-280$.
} 
bergantung pada al-Qur'an, hadis, tetapi juga melihat para sarjana yang lebih lunak, analisis linguistik dan menyelidiki implikasi dari penggunaan bahasa yang berbeda pada makna, termasuk bacaan metaforis dari beberapa jenis ayat. ${ }^{10}$

Selain kategorisasi di atas terdapat juga kategorisasi tafsir al-Qur'an berdasarkan periodenya yaitu periode klasik dan periode modern. Periode ditandai dengan semua interpretasi al-Qur'an yang dapat ditelusuri kembali ke sumber suara melalui rantai transmisi seperti Al-Qur'an itu sendiri dan interpretasi Nabi dan para sahabat.. Dalam definisi lain, ini adalah penafsiran yang mengandalkan Al-Qur'an, hadis Nabi, riwayat dari para ulama awal, bahasa Arab, dan puisi Arab pra-Islam. Dalam konteks ini, perlu disebutkan bahwa riwayat-riwayat isrā'îliyyāt (sumber-sumber al kitab) digunakan oleh umat Muslim paling awal untuk menafsirkan Al-Qur'an. ${ }^{12}$ Narasi Isrā'īliyyāt digunakan sebagai sumber sejarah yang tersedia sebagian besar untuk menafsirkan kisah-kisah para nabi sebelumnya, sehingga riwayat tersebut juga dimasukkan dalam penafsiran berbasis tradisi. ${ }^{13}$

Sedangkan periode modern ditandai dengan munculnya sejumlah cendekiawan modern seperti misalnya $\mathrm{M}$. Abduh yang menggunakan pendekatan tafsir bi-almaūthūr dengan cara yang sangat berbeda dari para penulis klasik. Sebagai contoh, Abduh menyangkal otoritas dan validitas hadis-hadis tertentu yang diriwayatkan dari generasi Muslim pertama dan tidak menerima relevansinya dengan interpretasi alQur'an. Menurut Abduh, interpretasi klasik harus ditolak karena mereka berusaha untuk mengklarifikasi hal-hal yang tidak dijelaskan oleh al-Qur'an, tidak mempertimbangkan konteksnya dan mengandalkan tradisi yang meragukan. ${ }^{14}$ Lebih lanjut mengenai penafsiran modern akan dijelaskan pada bagian berikutnya.

Namun sampai di sini setidaknya ada beberapa hal yang menurut hemat penulis cukup menarik. Pertama, pemaparan Hakan Çoruh mengenai tradisi tafsir bil-ma'thūr dan tafsir pada periode klasik tampak sama sekali hanya berbeda pada penggunaan riwayat Isrā'îliyyāt pada periode klasik saja. Kedua, terdapat juga penggunaan pendekatan bil-ma'thūr yang pada periode modern dengan contoh M. Abduh yang justru dikatakan berbeda dengan periode klasik. Sehingga apakah pengkategorisasian di atas terutama soal periodesasi hanya berpatokan pada urutan waktunya saja atau juga ada ketentuan lain dan apa implikasinya terhadap corak penafsiran al-Qur'an.

Artikel ini akan membahas mengenai corak penafsiran al-Qur'an mulai dari periode klasik sampai dengan modern. Sependek pengamatan penulis mengenai literatur yang membahas topik tersebut, pembahasan mengenai corak penafsiran alQur'an didominasi oleh pembahasan yang secara terpisah membahas corak-corak

${ }^{10}$ Çoruh, Modern Interpretation of the Qur'an, 8-9.

${ }^{11}$ Ahmad von Denffer, 'Ulūm Al-Qur'ān: An Introduction to the Sciences of the Qur'ān (Leicester, U.K.: Islamic Foundation, 1994), 124.

${ }^{12}$ Abdullah Saeed, Interpreting the Qur'an: Towards a Contemporary Approach, 1 ed. (Routledge, 2005), 96, https://doi.org/10.4324/9780203016770.

${ }^{13}$ Hakan Çoruh, "Tradition, Reason, and Qur'anic Exegesis in the Modern Period: The Hermeneutics of Said Nursi," Islam and Christian-Muslim Relations 28, no. 1 (2 Januari 2017): 87, https://doi.org/10.108o/o9596410.2017.1280915.

${ }^{14}$ Çoruh, "Tradition, Reason, and Qur'anic Exegesis in the Modern Period,” 87. 
tertentu seperti artikel yang ditulis oleh Izatul Laila ${ }^{15}$, Abdurrahman Rusli Tanjung ${ }^{16}$, Atik Wartini ${ }^{17}$, Zuherni $\mathrm{AB}^{18}$ dan Lukman Hakim ${ }^{19}$. Meskipun ada juga artikel yang membahas corak-corak penafsiran mulai dari periode klasik dan modern, yaitu artikel yang ditulis oleh Danial ${ }^{20}$, Kusroni ${ }^{21}$ dan Ghilman Nursidin Syarief ${ }^{22}$. Sayangnya ketiga tulisan tersebut hanya memaparkan jenis-jenis corak-corak penafsiran al-Qur'an dan tidak menghadirkan perdebatan di dalamnya, terutama yang berkenaan dengan apa yang membedakan corak penafsiran pada periode klasik dan modern. Adapun tulisan dari Wely Dozan ${ }^{23}$ fokus terhadap shifting atau pergeseran penafsiran atas paradigma penafsiran klasik dan kontemporer. Maka tulisan ini akan mendiskusikan hal tersebut dengan menjawab beberapa pertanyaan sebagai berikut: (1) Bagaimana perkembangan corak penafsiran al-Qur'an mulai dari periode klasik sampai dengan modern? (2) Apa yang menjadi pembeda antara corak penafsiran pada periode klasik dan modern? (3) Apa yang membedakan tipologi penafsiran berdasarkan metode dan periodesasi?

Artikel ini akan dimulai dengan pembahasan mengenai kecenderungankecenderungan penafsiran pada periode klasik. Setalah itu pembahasan dilanjutkan dengan kecenderungan-kecenderungan penafsiran pada periode modern serta kontradiktif yang muncul pada periode ini terhadap periode sebelumnya. Di akhir artikel akan ditutup dengan kesimpulan berupa jawaban atas pertanyaan-pertanyaan di atas dengan berpatokan terhadap bahasan yang sudah dipaparkan sebelumnya.

\section{Corak-corak Penafsiran Al-Qur'an}

Menurut Islah Gusman, corak tafsir atau yang dalam bukunya disebut dengan istilah 'nuansa tafsir', berarti sudut pandang yang paling dominan dalam sebuah penafsiran. ${ }^{24}$ Sudut pandang tersebut banyak dipengaruhi oleh latar belakang serta kemampuan intelektual seorang penafsir, hal ini yang menjadikan corak tafsir menjadi beragam sesuai dengan perkembangan zaman. ${ }^{25}$ Tidak lupa pengaruh dari lingkungan sosial politik di mana penafsir hidup. ${ }^{26}$ Dalam mengkategorikannya corak-corak para

15 Izzatul Laila, "Penafsiran Al-Qur'an Berbasis Ilmu Pengetahuan," Epistemé: Jurnal Pengembangan Ilmu Keislaman 9, no. 1 (10 Juni 2014): 45-66, https://doi.org/10.21274/epis.2014.9.1.45-66.

${ }^{16}$ Abdurrahman Rusli Tanjung, "Analisis terhadap Corak Tafsir Al-Adaby Al-Ijtima’i," Analytica Islamica 3, no. 1 (2014): 162-88.

${ }^{17}$ Atik Wartini, “Corak Penafsiran M.Quraish Shihab dalam Tafsir Al-Misbah,” HUNAFA: Jurnal Studia Islamika 11, no. 1 (19 Juni 2014): 109-26, https://doi.org/10.24239/jsi.v11i1.343.109-126.

${ }^{18}$ Zuherni AB, "Tafsir Isyari dalam Corak Penafsiran Ibnu 'Arabi," Al-Mu'ashirah 13, no. 2 (Juli 2016): 131-43.

${ }^{19}$ Lukman Hakim, "Corak Feminisme Post-Modernis dalam Penafsiran Faqihuddin Abdul Kodir," Jurnal Studi Ilmu-Ilmu al-Qur'an dan Hadis 21, no. 1 (Januari 2020): 231-53.

${ }^{20}$ Danial, “Corak Penafsiran Al-Qur'an Periode Klasik hingga Modern,” Hikmah XV, no. 2 (2019): 70-102.

${ }^{21}$ Kusroni, “Menelisik Sejarah dan Keberagaman Corak Penafsiran Al-Qur'an," El-Furqania o5, no. 02 (Agustus 2017): 132-46.

${ }^{22}$ Ghilman Nursidin Syarief, "Metode dan Corak Penafsiran al-Qur'an” o1 (2019): 10.

${ }^{23}$ Wely Dozan, "ANALISIS PERGESERAN SHIFTING PARADIGM PENAFSIRAN: STUDI KOMPARATIF TAFSIR ERA KLASIK DAN KONTEMPORER,” At-Tibyan: Jurnal Ilmu Alqur'an dan Tafsir 5, no. 1 (2020): 37-55, https://doi.org/10.32505/tibyan.v5i1.1631.

${ }^{24}$ Gusmian, Khazanah tafsir Indonesia, 231.

${ }^{25}$ Muhammad Ali Iyyazi, Al-Mufassirun; Hayatuhum wa Manhajatuhum (Teheran: 'Ulum alIslamy, 1414), 33.

${ }^{26}$ Abdul-Raof, Schools of Qur'anic Exegesis, 2. 267 | al-\$urhan: Kajian Ilmu dan Pengembangan Budaya Al-Qur'an, Vol. 20, No. 2, Desember 2020: $263-280$. 
sarjana tidak seragam. Misalnya Abd al-Hayay al-Farmāwī membagi corak tafsir ke dalam tujuh kategori yaitu: ma'tsur, ra'yi, fiqh, sufi, falasifah, 'ilmī, al-adab wa alijtimā $\hat{\imath}^{27}$ Sedangkan M. Quraish Shihab membagi corak tafsir ke dalam enam kategori yaitu: sastra bahasa, penafsiran ilmiah, filsafat dan teologi, fikih atau hukum, tasawuf, sastra budaya kemasyarakatan, Ilmi, dan terakhir adabi Ijtimai. ${ }^{28}$

\section{Penafsiran Al-Qur'an Periode Klasik}

Di pendahuluan sebelumnya telah disebutkan bahwa secara periode, penafsiran terbagi menjadi periode klasik dan modern. Meskipun ada juga pendapat lain, yaitu yang dikemukakan oleh Hakan Çoruh bahwa terdapat satu periode sebelumnya, yaitu periode formatif. Periode tersebut tidak akan menjadi pembahasan dalam artikel ini karena menurut Çoruh sendiri, pada periode ini penafsiran al-Qur'an belum ditulis dalam bentuk teks dan masih berupa tradisi lisan. ${ }^{29}$ Meskipun jangan dilupakan juga bahwa tafsir Al-Qur'an dibagi menjadi dua kategori besar: tafsir bi-al-ma'thūr (penafsiran berbasis tradisi) dan tafsir bi-al-ra'y (penafsiran berbasis alasan). Mengapa dalam kategorisasi periode model penafsiran juga penting, karena terdapat kecenderungan yang lebih besar dalam periode klasik ini terhadap tradisi yang pertama.

Dalam periode klasik, tafsir Jāmi 'al-Bayān'an Ta'wı $\bar{A}$ y al-Qur'an karya Ibnu Jarir at Thabari ${ }^{30}$ adalah sumber paling signifikan dari penafsiran berbasis tradisi. Terlebih lagi, korpus pertama yang diterima dalam tradisi penafsiran Sunni adalah berdasarkan tradisi penafsiran Tabarı. ${ }^{31}$ Selanjutnya, penafsirannya memuat sekitar 37.000 narasi eksegesis dengan rantai transmisi dari Nabi Muhammad, para sahabat, para tabiin sampai pengikut para tabiin, di mana ia menyajikan upaya untuk memahami al-Qur'an yang pertama kali setelah 3 Abad sepeninggal nabi dalam bentuk tulisan. Dia juga memperjelas pandangannya tentang beragam pendapat dari penafsir sebelumnya. Selain itu, karya ikoniknya ini adalah yang pertama untuk menggabungkan sepenuhnya berbagai tahap formatif atau elemen penafsiran Muslim terdahulu. ${ }^{32}$ Untuk alasanalasan ini, Tafsir Tabarı adalah sangat penting dalam studi al-Qur'an.

Penafsiran berbasis tradisi penting lainnya adalah karya Ibn al-Kathir (w. $774 \mathrm{H}$ ) yaitu Tafsı̄ al-Qur'ān al-'Azım .33 Penafsiran Ibn al-Kathir adalah salah satu karya tafsir ensiklopedis yang menggunakan tradisi Tabarı. ${ }^{34}$ Seperti penafsiran Tabarı, penafsirannya mengandung banyak bahan tradisional, namun, berbeda dengan Tabarı, Ibn al-Kathir mencoba kritis terhadap sumber-sumber tradisional tersebut. Sehingga penafsirannya dianggap paling tertata, juga terevaluasi. ${ }^{35}$ Dia memeriksa dan

\footnotetext{
${ }^{27}$ Al-Farmawi Abdul Hayy, Metode Tafsir Maudhu'i Dan Cara Penerapannya, trans. oleh Rosihan Anwar (Bandung: Pustaka Setia, 2002), 23.

${ }^{28}$ M. Quraish Shihab dan Ihsan Ali-Fauzi, "Membumikan" Al-Qur'an: fungsi dan peran wahyu dalam kehidupan masyarakat (Bandung: Mizan, 2002), 72.

${ }^{29}$ Çoruh, Modern Interpretation of the Qur'an, 8.

${ }^{30}$ TTabarı, Jāmi al-Bayān'an Ta'wit Ày al-Qur'an (Cairo: Hacr, 2001).

${ }^{31}$ Claude Gilliot, Exegesis of the Qur'ān: Classical and Medieval (Leiden-Boston: Brill, 2002), 110.

${ }^{32}$ Peter G Riddell, "Al-Tabari," dalam The Qur'an: an Encyclopedia, ed. oleh Oliver Leaman (London-New York: Routledge, 2006), 623.

${ }^{33}$ Ab al-Feda Ibn Kathır, Tafsır al-Qur'a'n al-'Azım (Cairo: Maktabat Avlad Al Shaykh Let- Turāth and Muassasat Qurtuba, 2000).

${ }^{34}$ Andrew Rippin, "Tafsir," dalam The Encyclopaedia of Religion (New York: Macmillan, 1987), 13.

${ }^{35}$ Jane Dammen McAuliffe, Qur'änic Christians: an Analysis of Classical and Modern Exegesis (Cambridge: Cambridge University Press, 2007), 76. 
mengevaluasi tradisi penafsiran menurut konsepsinya yang agak ketat dalam cara gurunya Ibn Taymiyya (w. $1328 \mathrm{M}) .{ }^{36}$ Penting untuk dicatat juga bahwa penafsiran Ibn al-Kathir merupakan titik balik dalam literatur penafsiran al-Qur'an. Norman Calder menggarisbawahi bahwa Ibn al-Kathī̄ memiliki kecenderungan Sunni yang kuat, menolak penafsiran berdasarkan alasan belaka dan memiliki pendekatan kritis terhadap sumber isrā'liyyāt. Ibn al-Kathī̄̄ secara umum tidak menyukai pembacaan polivalen, dia lebih cenderung bersikeras atas 'kebenaran' tunggal dalam pembacaannya. Selain itu, ia dan mentornya, Ibn Taymiyya, mewakili daya tarik dari otoritas komunitas dan otoritas independen dari para ulama, serta tidak mempercayai tradisi intelektual Islam dan dari pengalaman yang dikumpulkan komunitas Muslim. ${ }^{37}$

Berpindah ke penafsiran berbasis alasan, pada periode klasik, keprihatinan teologis juga mulai memiliki efek yang lebih besar pada tafsir Al-Quran, dan tren ini menghasilkan tafsir al-Qur'an yang paling terkenal di dunia Muslim. Perdebatan menjadi pertanyaan utama dalam teologi Islam dan berbagai posisi yang dapat ditemukan dalam Al-Qur'an. Kehendak bebas (free will) dan takdir, sifat-sifat Allah, sifat Al-Qur'an, pengenaan tugas-tugas hukum, dan sifat dan tingkat akhirat adalah beberapa topik utama. ${ }^{38}$ Menurut A. Saeed, para teolog dari mazhab Mu'tazilah dan Ash'ariah atau yang dikenal dengan istilah Sunni berkontribusi lebih banyak pada penafsiran teologis daripada para teolog lainnya. ${ }^{39}$

Salah satu tafsir teologis yang paling menonjol adalah al-Kashshaf an Haqaiq alTanzil karya al-Zamakhsharı (w. $538 \mathrm{H}$ ) seorang Mu'tazilah yang ahli di bidang tata bahasa dan filologi, ${ }^{40}$ yang berisi intisari dari doktrin Mu'tazilah. Meski demikian, reputasinya sebagai seorang penafsir al-Qur'an lebih banyak bertumpu pada kualitasnya sebagai seorang ahli ilmu bahasa dan filologi, serta kritik retoris dan sastra. Karena alasan ini, ia dihargai di kalangan arus utama Sunni hingga hari ini. ${ }^{41}$

Dalam penafsiran berbasis alasan, ada juga dua sumber penting yang berkaitan dengan penafsiran al-Zamakhsharı. Salah satunya adalah Anwār al-tanzīl wa-asrār alta'wīl karya seorang teolog al-Bayḍāwī (w. $716 \mathrm{H}$ ) bermazhab Syafi'i. ${ }^{42}$ Al-Bayḍāwī mengurangi penafsiran al-Zamakhsharī di bagian-bagian di mana opini Mu'tazilī dihasilkan. Di sisi lain, ia juga memperluasnya dengan perincian dari sumber-sumber lain, serta mengasimilasi teori Mu'tazilah ke dalam arus utama Sunni. Para teolog Sunni percaya bahwa tafsir al-Bayḍ̄āī adalah yang terbaik. ${ }^{43}$ Selain itu, komentarnya menjadi salah satu interpretasi paling populer di dunia Muslim, dan telah menjadi subjek banyak glosarium seperti Gloss of al-Kāzarūnī ${ }^{44}$ Adapun sumber lainnya, itu adalah Madārik al-

${ }^{36}$ Gilliot, Exegesis of the Qur'ān: Classical and Medieval, 113.

${ }^{37}$ Norman Calder, "Tafsir from Tabari to Ibn Kathir: Problems in the Description of a Genre, Illustrated with Reference to the Story of Abraham,” dalam Approaches to the Qur'an, ed. oleh G. R. Hawting dan AbdulKader A. Shareef (London: Routledge, 1993), 101-139.

${ }^{8}$ Rippin, "Tafsir," 12.

${ }^{39}$ Saeed, Abdullah, "Qur'an: Tradition of Scholarship And Interpretation," dalam Encyclopedia of Religion, ed. oleh Lindsay Jones (Detroit: Macmillan Reference, 2005), 7566.

${ }^{\circ}$ Zamakhshari, al-Kashshaf an Haqaiq al-Tanzil (Beirut: Dar al-Marifah, t.t.).

${ }^{41}$ Gilliot, Exegesis of the Qur'ān: Classical and Medieval, 115.

${ }^{42}$ Al-Baydāwıı, Anwār al-tanzıl wa-asrār al-ta'wıl (Beirut: Dar Ehia Al-Tourath Al-Arabi, t.t.).

${ }^{43}$ Helmut Gätje, The Qur'an and Its Exegesis (Oxford: Oneworld Pub., 20o8), 37; Peter G Riddell, "Al-Baydawi," dalam The Qur'an: an Encyclopedia, ed. oleh Oliver Leaman (London-New York: Routledge, 2006), 117.

${ }^{44}$ Gilliot, Exegesis of the Qur'ān: Classical and Medieval, 116. 269 | at-Burhan: Kajian Ilmu dan Pengembangan Budaya Al-Qur'an, Vol. 20, No. 2, Desember 2020: $263-280$. 
tanzīl wa haqā’iq al-ta’wīl karya Abū al-Barakāt al-Nasafî (w. 710 H) seorang teolog bermazhab Hanafi. ${ }^{45}$ Karya ini adalah ringkasan penafsiran yang mungkin menyenangkan sebagian besar aliran Sunni. ${ }^{46}$ Patut disebutkan bahwa al-Nasafi telah menulis penafsirannya untuk mempertahankan Islam arus utama terhadap penafsiran al-Zamakhsharī yang memuat gagasan Mu'tazilah. Dia menghapus kredo dan pendapat Mu'tazilah al-Zamakhsharī. Namun, ia memanfaatkan penafsiran al-Zamakhsharı secara bebas dalam banyak topik lain, khususnya, dalam retorika dan tata bahasa. Terkadang dia meringkas al-Kashshaf, dan terkadang menambahkan informasi tambahan. ${ }^{47}$

Selain itu terdapat juga tafsir teologis yang tidak kalah penting yaitu Mafātıh̆ alGhayb karya Fakhr al-Dı̄n al-Rāzı (w. 1210 M). ${ }^{48}$ Di mana Al-Rāzī menafsirkan al-Qur'an dengan pengetahuan filosofis dan teologis. Menurut McAuliffe, dalam hal metode dan susunannya, paling dekat dengan paralel Barat semi modern dengan eksegesisnya adalah Summa Theologiae dari Thomas Aquinas (w. 1274 M). Penulis biografinya, alSafadī, menyatakan tentang metodenya: "Fitur yang sering dicatat dari penelitian alRāzı adalah sikap anti-Mu'tazilah dan pertahanannya yang kuat terhadap Ash'arī Sunnisme." perlu dicatat bahwa tafsir Sunni al-Qur'an yang produktif mencapai kesimpulan yang sama dengan penafsiran Rāzı. ${ }^{49}$ Komitmen Rāzı memiliki signifikansi untuk tafsir teologis, filosofis, tasawuf, ilmiah, dan retoris.

Pada periode klasik pula muncul bidang ilmu-ilmu al-Qur'an khusus, menyediakan sejumlah sub-disiplin dalam tafsir al-Qur'an salah satu yang dan yang paling penting yaitu disiplin ilmu bernama Ulūm al-Qur'an (ilmu-ilmu Al-Qur'an). Salah satu sumber terpenting mengenai topik ini adalah al-Itqān fi Ulüm al-Qur'an karya al-Suyūtı (w. $91 \mathrm{H}) .{ }^{50}$ Beberapa topik dalam kitab ini adalah mengenai pencabutan beberapa ayat al-Qur'an, kesempatan wahyu dan tak dapat ditirunya al-Qur'an. ${ }^{51}$ Menurut Claude Gilliot, dapat dikatakan bahwa kitab Burhān karya al-Zarkashı' (w. 794 H) dan kitab Itqān karya al-Suyūtı' menunjukkan hasil studi Islam berabad-abad tentang al-Qur'an. Mereka tetap menjadi sumber utama sampai hari ini, khususnya Itqān, bagi orang-orang yang menulis buku pegangan baru dalam bahasa Arab tentang ilmu-ilmu al-Qur'an. Sebagai contoh, kitab Mabāhith karya al-Qatțan ${ }^{52}$ dapat dianggap sebagai jenis ringkasan dari Itqān. ${ }^{53}$ Oleh karena itu, Itqān al-Suyūtı merupakan hal yang sangat penting bagi ilmu-ilmu al-Qur'an klasik.

Salah satu jenis penafsiran penting pada periode klasik adalah penafsiran tasawuf. Ini didasarkan pada pendapat yang berkembang di kalangan Muslim Sufi sekitar abad kedua hijriah. Para penafsir tasawuf menekankan aspek spiritual Islam, dan menganggap bahwa kiasan mistis dalam teks al-Qur'an berhubungan paling dekat

\footnotetext{
${ }^{45}$ al-Nasafi, Tafsır al-Nasafi- (Mada-rik al-tanzıl wa h. aqā’iq al-ta'wll) (Istanbul: Kahraman Yay., 1984).

${ }^{46}$ Gilliot, Exegesis of the Qur'ān: Classical and Medieval, 113.

${ }^{47}$ Muhsin Demirci, Tefsir Tarihi (Istanbul: IFAV, 2003), 179.

${ }^{48}$ Fakhr al-Dın Razi, Mafātıh al-Ghayb (Beirut: Dar al-Fikr, 1981).

${ }^{49}$ Gätje, The Qur'an and Its Exegesis, 37.

${ }^{50}$ al-Suyūtı, al-Itqān fi Ulūm al-Qur'an (Riyadh: Mucamma' Al Malik Fahd Li Tibae Al Mushaf Al Shareef, t.t.).

${ }^{51}$ Rippin, "Tafsir," 13-14.

${ }^{52}$ Manna Khalil al-Qattan, Mabahiş fi 'Ulum Qur'an (Kairo: Maktabah Wahbah, t.t.).

${ }^{53}$ Gilliot, Claude, "Traditional Disciplines of Qur'ānic Studies," dalam Encyclopaedia of the Qur'ān, ed. oleh Jane Dammen McAuliffe (Leiden-Boston: Brill, 2006), 335.

at OBurhan: Kajian Ilmu dan Pengembangan Budaya Al-Qur'an, Vol. 20, No. 2, Desember 2020: 263-280 | 270
} 
dengan kondisi spiritual manusia dan tidak mungkin untuk dipahami melalui pembacaan dangkal atas poin-poin hukum dan teologi. Oleh karena itu makna spiritual dan batin dari al-Qur'an lebih penting dalam tafsir ini. ${ }^{54}$ Salah satu karya paling penting dari literatur tasawuf adalah Haqā'iq al-Tafsır karya al-Sulami (w. 412H). ${ }^{55}$ Karya ini berkontribusi pada pembentukan penafsiran tasawuf sebagai cabang independen dari hermeneutika al-Qur'an, dan menyusun banyak interpretasi Șufī dari masa lalu. Oleh karena itu, dalam hal ini, karya al-Sulami dalam penelitian tasawuf adalah seperti tafsir Tabarı yang mengkompilasi tradisi sebelumnya dalam tafsir Sunni. ${ }^{56}$ Sumber lainnya yaitu al-Risāla al-Qushayriyya karya al-Qushayri (w. $465 \mathrm{H}) .{ }^{57}$

Selain para penafsir di atas, banyak penafsir terkemuka menulis komentar tentang al-Quran hingga menjelang periode modern. Beberapa karya yang perlu dilihat misalnya Irshād al-Qaql al-Salım karya Abū al-Suud (w. $982 \mathrm{H}$ ), yang merupakan penafsiran berdasarkan alasan; Fatḥ al-Qadı̄ karya Shawkānı (w. 1250H), menggabungkan interpretasi berbasis tradisi dan alasan Rūh al-Ma 'ānı karya al-Ālūsı (w. 1270 H), yang merupakan komentar klasik dan sufi; dan Hak Dini Kur'an Dili karya Elmalılı Hamdi Yazır (w. 1942 M), sebuah komentar berdasarkan alasan.

\section{Penafsiran Al-Qur'an Periode Modern}

Di masa modern, sementara penafsiran Al-Qur'an gaya klasik berlanjut, berbagai bacaan dan interpretasi al-Qur'an muncul melalui dampak pemikiran Barat dan modernisme di beberapa wilayah Muslim seperti India dan Mesir pada abad ke-19 dan ke-20. Beberapa ciri khas utama dari bacaan modern ini adalah sebagai berikut: Perhatian utama adalah al-Qur'an; pendekatan skeptis terhadap hadıs; menolak berbagai mazhab Islam dan ijma (konsensus para ulama); mengklaim ketidakcukupan ilmu al-Qur'an; umumnya menyangkal pencabutan dalam al-Qur'an; menekankan hubungan antara ayat dan surat (Munāsabāt al-Qur'an); pendekatan kritis terhadap israiliyat; tidak memberi arti penting bagi tak dapat ditirunya al-Qur'an secara filologis; menafsirkan al-Qur'an berdasarkan nalar dan sains modern. ${ }^{58}$

Salah satu tren utama dalam penafsiran modernis adalah menafsirkan al-Qur'an dari perspektif rasionalisme Pencerahan. ${ }^{59}$ Tafsır Qur Al-Qur'ā Al-Hakım al- mushtaher bismi Tafsī al-Manār karya Muhammad Abduh (w. 1905 M) dan muridnya M. Rashid Riḍā (w. 1935M), termasuk ciri-ciri karakteristik penafsiran modernis.

Tren penting lainnya di zaman modern adalah penafsiran ilmiah. Para pendukung tafsir semacam ini berpendapat bahwa segala macam temuan ilmu alam modern telah diramalkan dalam al-Qur'an dan bahwa banyak referensi yang jelas tentang hal itu dapat ditemukan dalam ayat-ayatnya. Perlu dicatat bahwa ada juga contoh dasar eksegesis ilmiah pada periode klasik. Beberapa penafsir al-Qur'an pada periode klasik, seperti Fakhr al-Dı̄n al-Rāzı, 'telah menyatakan pendapat bahwa semua ilmu terkandung dalam al-Qur'an. Namun, metode ini ditolak oleh beberapa sarjana dari periode klasik seperti al-Shātịbī (w. 1388 M) dan modern seperti Sayyid Qutḅ (w.

\footnotetext{
${ }^{54}$ Saeed, The Qur'an, 205-6.

55 al-Sulamı, Haqā’iq al-tafsı̄̄ (Beirut: Dar Al-Kutub Al-Ilmiyya, 2004).

${ }^{56}$ Gilliot, Exegesis of the Qur'ān: Classical and Medieval, 120.

${ }^{57}$ al-Qushayri, al-Risāla al-qushayriyya (Beirut: Al-maktaba Al-assrya, 2008).

${ }^{58}$ Çoruh, Modern Interpretation of the Qur'an, 12.

59 Rotraud Wielandt, "Exegesis of the Qur'àn: Early Modern and Contemporary," dalam Encyclopaedia of the Qur'ān, ed. oleh Jane Dammen McAuliffe (Leiden-Boston: Brill, 2002), 126. 271 | at-@urhan: Kajian Ilmu dan Pengembangan Budaya Al-Qur'an, Vol. 20, No. 2, Desember 2020: $263-280$.
} 
1966 M). ${ }^{60}$ Sumber penting penafsiran ilmiah adalah al-Jawāhir fì tafsı̄̄ al-Qur'ān alkarım karya Țantạ̄ wījawharı (w. 1940 M). ${ }^{61}$ Tidak seperti kebanyakan penafsir ilmiah yang tertarik pada "sifat ajaib ilmiah dari Al-Qur'an ", tujuan utama Jawhar adalah untuk mendorong umat Islam untuk belajar dan mengetahui ilmu-ilmu karena ia melihat mereka sebagai faktor utama yang mendorong masyarakat modern menuju pembangunan. $^{62}$

Ada beberapa sumber yang berguna untuk memahami penelitian modern: Salah satunya adalah Modern Muslim Koran interpretation (1880-1960) karya Johannes Marinus Simon Baljon. ${ }^{63}$ Karya ini berfokus pada beberapa topik seperti cara penafsiran intelektual modern dan karakteristik al-Qur'an dalam konteks eksegesis modernis. Baljon meneliti karya tiga penafsir modernis dari wilayah India-Pakistan: Abu al-Kalam Āzad̄ (w. 1958 M), al-Mashriqı (w. 1963 M), Ghulam̄ Ahmad Parwez (w. 1985 M); dan dia juga menyebutkan beberapa cendekiawan penting seperti Ahmad Khan, Muhammad A. Khalafallah (w. 1991 M), Sayd Qutḅ dan Muhammad Iqbal (w. 1938 M).

Dalam pembahasan mengenai cara penafsiran intelektual modern, Baljon memulai dengan membahas penolakan kelompok modernis atas penggunaan tradisi israiliyat dan pengaruh budaya Byzantium dan Iran saat menguraikan kisah-kisah alQur'an. Salah satu prinsip utamanya adalah bahwa penjelasan terbaik al-Qur'an adalah yang dilakukan oleh al-Qur'an itu sendiri. Hal itu mengacu kepada al-Qur'an surat AlQiyaamah ayat QS [75]:19. Mayoritas modernis India-Pakistan berpendapat bahwa detail historis dalam al-Qur'an yang berasal dari tradisi, harus dianggap murni sebagai produk imajinasi manusia. Menurut Ahmad Khan, al-Qur'an sendiri mengisyaratkan perbedaan antara cerita buatan manusia dengan pesan ilahiahnya. Contohnya terdapat kisah Ashabul Kahfi dalam QS [18]:12-13. Bagi Khan, kata "bi'l haqqi” dalam ayat 13 menjadi indikasi bahwa ayat sebelumnya bukanlah cerita yang ingin tuhan ceritakan, namun hal itu adalah cerita yang sudah dikenal oleh khalayak. ${ }^{64}$ Senada dengan ini pendapat Al Makin mengenai pengisahan cerita masa lalu dalam al-Qur'an bukanlah upaya menghadirkan kembali dialog historis ribuan tahun lalu melainkan kontekstualisasi narasi lama untuk kepentingan misi dakwah pada saat al-Qur'an turun. ${ }^{65}$

Selanjutnya dokumentasi terbaik yang menyerang tradisi-tradisi penafsiran klasik terdapat dalam 2 jilid buku berjudul Maqam Hadith (1957) karya Parwez, terutama yang menyerang penafsir al-Qur'an yang terlalu fokus kepada hadis sebagai sumber rujukan. Dalam hal ini terdapat beberapa argument Parwez yang digunakannya, antara lain: Pertama, ketika banyak penafsir pada periode klasik menafsirkan kata 'hikmah' dalam QS [2]:123-129 sebagai ‘hadis' nabi, Parwez beranggapan tidak demikian. Menurutnya kata 'hikmah' di situ bermakna kebijaksanaan secara umum, tidak khusus kepada nabi Muhammad. Dia mencontohkan misalnya pada QS [31]: 11-12, kata 'hikmah'

\footnotetext{
${ }^{60}$ Wielandt, "Exegesis of the Qur'ān: Early Modern and Contemporary," 129-31.

${ }^{61}$ Tantāwı Jawharı, al-Jawāhir fi tafsı' $r$ al-Qur'a'n al-karım (Egypt: Mustafa. Al-Bābı Al-Halabı, $1350)$.

${ }^{62}$ Saeed, Abdullah, "Qur'an: Tradition of Scholarship And Interpretation," 7567.

${ }^{63}$ Johannes Marinus Simon Baljon, Modern Muslim Koran Interpretation (1880-1960) (Leiden: E. J. Brill, 1968).

${ }^{64}$ Baljon, Modern Muslim Koran Interpretation (1880-1960), 17.

${ }^{65}$ Al Makin, Keragaman dan perbedaan: Budaya dan Agama dalam Lintas Sejarah Manusia (Yogyakarta: Suka Press, 2016), 37.

at-§urhan: Kajian Ilmu dan Pengembangan Budaya Al-Qur'an, Vol. 20, No. 2, Desember 2020: 263-280 | 272
} 
yang diberikan Allah kepada Lukman, lalu diartikan bahwa Lukman menerima tradisi dari nabi Muhammad, sedangkan nabi Muhammad adalah nabi terakhir.

Kedua, otoritas profetik nabi yang tertulis dalam QS [59]:7 yang artinya "Apa yang diberikan Rasul kepadamu, maka terimalah. Dan apa yang dilarangnya bagimu, maka tinggalkanlah." Menurutnya ayat ini hanya berkaitan dengan distribusi hasil rampasan pada masa tertentu, tidak berarti makna yang umum. Terlebih kata 'ata' dalam ayat tersebut berarti memberi tidak dapat diartikan sebagai 'mengatakan' atau 'memerintahkan'.

Ketiga, pendapat para penafsir klasik yang menarik kesimpulan dari ayat QS [53]:3, bahwa apapun yang diucapkan nabi adalah wahyu menurut Parwez tidak masuk akal. Menurutnya tidak mungkin semua yang dikatakan nabi adalah wahyu, yang termasuk di dalamnya ucapan-ucapan nabi yang bersifat domestik rumah tangganya. Terakhir, pada ayat mengenai perintah Allah untuk menaati rasul sebagai imama pada QS [24]:54, yang mengatur umma, di mana ketika Nabi wafat dilanjutkan kepada khalifah dan sekarang kepada pemerintah, menunjukkan bahwa al-Qur'an menunjukkan perbedaan antara mengimani al-Qur'an dan hadis.

Lebih jauh, salah satu keberatannya terhadap tradisi-tradisi itu adalah bahwa teks-teks al-Qur'an terbatas pada makna tertentu, sedangkan wawasan manusia tentang Kitab Suci bertumbuh seiring perkembangan zaman. Contohnya kasus penyelamatan Allah atas jasad Firaun pada zaman nabi Musa, yang dicatat dalam QS [10]:92. Saat ini hal itu dipahami setelah penemuan mumi Ramses II. ${ }^{66}$

Gagasan utama Parwez adalah bahwa tidak semua yang diucapkan Nabi adalah wahyu. Karena menurutnya jika semua yang dikatakan Nabi adalah wahyu, lalu mengapa Allah mengkritisi keputusan Nabi seperti pada QS [9]:43. Argumen lainnya adalah jika memang semua yang dikatakan Nabi adalah wahyu lalu mengapa Nabi harus menunggu wahyu untuk sesuatu yang yang belum ada dalil al-Qur'an-nya. Misalnya pada kasus arah kiblat yang semula menghadap ke Yarusalem, tetapi dalam hatinya besar keinginan untuk menghadap Ka'bah sebagai kiblat. Dalam hal ini nabi tidak dapat memutuskannya sendiri sampai turun ayatnya. ${ }^{67}$

Selain Parwez terdapat juga penafsir lainnya bernama Ahmad Khan, seorang yang ahli di bidang bahasa (lexical). Dalam pandangannya selalu ada kemungkinan bahwa beberapa kata dalam al-Qur'an tidak dapat didekati dengan pendekatan lingustik atau ilmu bahasa.

Masih mengenai bahasa, kritik lain juga muncul dari Khalafallah. Menurutnya terkadang makna harfiah dari kata-kata itu telah terlalu dipegang teguh, tanpa memperhatikan keunikan komposisi dan latarbelakang psikologis dari sebuah terminologi. Misalnya penafsiran Zamakhshari dalam kitab al-Kashshaf, yang menafsirkan tiga jenis ular dalam narasi nabi Musa dalam al-Qur'an yakni al-djan, althu'ban dan al-hayya. Zamakhshari menyelaraskan materi yang tersedia dengan cara ini sehingga pada awalnya akan ada ular kecil (al-hayya) yang lambat laun berkembang menjadi lebih besar (al-thu'ban). Dan al-Djan adalah yang terbesar dari ketiganya. Tetapi intinya adalah bahwa dalam kisah-kisah ini istilah al-djan hanya digunakan ketika dimaksudkan untuk menyampaikan teror yang diilhami olehnya. Karena itu kita membaca setelah al-djan (dalam kisah staf yang bergerak): "dia berbalik melarikan diri"

\footnotetext{
${ }^{66}$ Baljon, Modern Muslim Koran Interpretation (1880-1960), 17-18.

${ }^{67}$ Baljon, Modern Muslim Koran Interpretation (1880-1960), 19. 273 | al-\$urhan: Kajian Ilmu dan Pengembangan Budaya Al-Qur'an, Vol. 20, No. 2, Desember 2020: $263-280$.
} 
QS. [27]: 10. Namun, istilah hayya dan thu'ban digunakan ketika tidak perlu menggambarkan efek dari ketakutan. ${ }^{68}$

Keberatan Khalafullah berikutnya terhadap para penafsir klasik adalah berkaitan dengan penggunaan aspek sejarah atau historis yang terlalu berlebihan. Dia menganggap tidak perlu seorang penafsir mencari informasi detail mengenai kejadiankejadian masa lalu, karena menurut Al-Quran, legitimasi sejati seorang nabi tidak terletak pada pengetahuannya tentang fakta-fakta empiris, tetapi dalam pengetahuannya atas dunia yang tidak terlihat seperti yang ditegaskan dalam QS $[3]: 44 .^{69}$

Dan terakhir penialian Khalafullah adalah berkenaan dengan spekulasi teoritis penafsir klasik, terutama Fakhr al-Din al Razi. Menurutnya Razi terlalu tenggelam dengan diskurususnya sendiri. Misalnya berkaitan dengan QS [36]:10, di mana Razi terlalu larut dalam diskusi yang tidak produktif seperti membahas al-qada wal qadar (nasib dan takdir), padahal sejatinya bukan tujuan al-Qur'an dalam bagian ini. ${ }^{70}$

Selanjutnya modernisme Muslim telah sangat terkesan oleh kekuatan nalar, dan terus terpesona olehnya, bahkan ketika di Eropa rasionalisme telah lama memberi tempat pada vitalisme dan eksistensialisme. Karena itu, salah satu tujuan utama dari penafsiran al-Qur'an modern adalah untuk menghapus teks dari sifat-sifat legenda dan gagasan primitif. Untuk tujuan ini, kisah-kisah al-Qur'an 'direkonstruksi'. Maka Abdul Hakim mencatat ayat-ayat seperti pada QS [7]:170-171, kata seperti "Rafa'na fawqakumu" tidak mesti berarti benar-benar gunung ditempatkan di atas kepala mereka. Orangorang yang tinggal di daerah pegunungan tahu bahwa terkadang terdapat batu yang menonjol, yang jika digambarkan dengan bahasa sekarang mirip seperti kanopi, sehingga menciptakan kesan pada orang-orang di bawah ini yang akan jatuh di atas kepala mereka. Selain itu Parwez menganggap term 'min indillahi' dalam QS [3]:37 tidak berarti bahwa makanan untuk Maria datang langsung dari Tuhan tanpa sarana sekunder, karena penyembah Tuhan sering menerapkan ungkapan yang sama untuk hal-hal yang diperoleh dengan sarana sekunder. Oleh karena itu orang membawa bekal dengan kebaikannya sendiri, seperti yang dilakukan saat ini untuk serambi. ${ }^{71}$

Motif-motif dongeng juga dihapus oleh Parwez, misalnya pada QS 27:17, makna tair (burung), dapat berarti secara harfiah burung merpati yang melayani untuk tujuan perang atau secara kiasan diartikan sebagai kuda cepat (yaitu pasukan dengan kavaleri), atau klan yang disebut tair. Atau mengenai kata 'hudhud' ada waktu itu orang mungkin menamai burung dan hewan, seperti dalam Tora seorang Edom dari darah kerajaan diberikan nama Hadad. Metode yang paling sering digunakan dalam de-mitologisasi adalah dengan kemampuan leksikografis. Selain penghilangan semua hal supernatural yang disebutkan di atas secara konsisten dan disebutkan di atas, kita bertemu di antara kaum modernis yang lebih moderat, upaya untuk meminimalkan sebanyak mungkin elemen ajaib dari cerita itu. ${ }^{72}$

Selain penghilangan semua hal supernatural yang disebutkan di atas secara konsisten dan disebutkan di atas, kita bertemu di antara kaum modernis yang lebih

\footnotetext{
${ }^{68}$ Baljon, Modern Muslim Koran Interpretation (1880-1960), 20.

${ }^{69}$ Baljon, Modern Muslim Koran Interpretation (1880-1960), 20.

${ }^{70}$ Baljon, Modern Muslim Koran Interpretation (1880-1960), 21.

${ }^{71}$ Baljon, Modern Muslim Koran Interpretation (1880-1960), 21-22.

${ }^{72}$ Baljon, Modern Muslim Koran Interpretation (1880-1960), 23.
} 
moderat, upaya untuk meminimalkan sebanyak mungkin elemen ajaib dari cerita itu. Ketika dalam QS [18]:63 diceritakan bahwa ikan Musa dan hambanya mengambil jalan di laut 'adjaban' (dalam jenis yang menakjubkan), maka 'adjaban' ini dijelaskan oleh Muh. Abduh sebagai: "sehingga nabi Allah takjub akan hal itu", suatu keheranan yang cukup dapat dimengerti, karena ia dan hamba-Nya "tidak memperhatikan ikan yang mereka bawa dalam keranjang, sehingga ia dapat menyelam ke laut " Karena kata-kata Yakub dalam QS [12]:94, "Saya menemukan bau Yusuf", Muh. Rashid Ridha mengamati bahwa, meskipun keajaiban tidak perlu aneh bagi orang-orang dari generasi kita yang diberkati, di sini kita hanya diberitahu tentang Yakub merasakan bau Yusuf di kemejanya. Bukan sepatah kata pun tentang bau, yang berasal dari Firdaus. Bau kemejanya tidak lain adalah bau badannya yang normal. ${ }^{73}$

Gagasan keagamaan yang lebih bersifat doktrinal juga dianggap dapat dirasionalisasikan oleh para modernis. Missal konsep 'mencintai Tuhan' dalam QS [2]:165, Tantawi Djawhari menjelaskan bahwa orang buta tidak dapat melihat gagasan keindahan bentuk dan orang tuli tidak tahu keindahan musik, kerena mereka tidak dapat membayangkannya. Menurutnya cinta akan didasarkan pada pengetahuannya, di mana tak kenal maka tak cinta. Yang menemukan kebenaran tentang Allah yang dibedakan atas keindahan, kekuatan, pengetahuan dan kemuliaan ..., datang dengan penuh semangat untuk mencintai kecantikan, pengetahuan, kekuasaan, dan kemuliaan-Nya. Sedangkan konsep cinta yang dimiliki para sufi dianggap terlalu puas dengan yang parsial, sehingga hal itu dianggap gagal merangsang murid-murid mereka untuk bersiap belajar pembelajaran Barat dan Timur. Ketika Pawrez menemukan permasalahan dalam menyelaraskan konsep keimanan kepada Tuhan yang bersifat ghaib dengan premis rasionalitas al-Qur'an pad QS [12]:108. Pertama konsep keimanan 'tanpa perlu melihat' itu dibutuhkan, sesederhana jika kelayakannya harus dibuktikan, itu harus dipraktikkan terlebih dahulu. Hal ini yang kemudian dikenal dalam Islam dengan istilah iman bi'l-ghaibi. Namun pada akhirnya ketika dalam kasus yang berat seorang materialis telah mencapai akhir dari pencariannya, jika beriman dia akan tetap berdoa. Meskipun di sisi lain dia menunjukkan adanya kemungkinan berhasilnya doa, baik dilihat sebagai Tuhan memberikan ‘tambahan' atau mengubah kepada takdir atau dari doa, seseorang mendapatkan efek psikologis dari doanya tersebut. ${ }^{74}$

Sedangkan menurut penafsir yang lebih bernada sangat relijius seperti Sayyid Qutb dalam menafsirkan taqwa pada QS [4]:131, dia mengatakan secara spesifik bahwa sifat pemeliharaan Allah semakin mendekat ketika hambanya mendekat kepada Allah. Senada dengan Qutb, Muh. Abduh pun menjelaskan ibadah itu mengarah kepada sikap penyerahan diri yang seutuhnya dan dengan kesadaran penuh tentang tauhid tanpa perlu mengetahui datang dari mana perasaan keimanan tersebut. Serta mengimani kekuasaan Allah tanpa mengetahui makna iman itu sendiri, orang yang beriman hanya merasakannya saja bahwa dia beriman. ${ }^{75}$

Pengaruh barat juga muncul dalam penerapan konsep psikologis pada penafsiran al-Qur'an modernis. Misalnya penafsiran Khalafullah mengenai dikirimnya Nabi Muhammad untuk orang arab dikarenakan kebutuhan atas kenabian yang berkaitan dengan kekosongan kenabian sejak nabi Isa. Hal ini dia anggap senada dengan

\footnotetext{
${ }^{73}$ Baljon, Modern Muslim Koran Interpretation (1880-196o), 24.

${ }^{74}$ Baljon, Modern Muslim Koran Interpretation (1880-1960), 25-26.

${ }^{75}$ Baljon, Modern Muslim Koran Interpretation (1880-1960), 25-26. 275 | al-@urhan. Kajian Ilmu dan Pengembangan Budaya Al-Qur'an, Vol. 20, No. 2, Desember 2020: $263-280$.
} 
permintaan Bangsa Yahudi dalam QS [20]:134 yang meminta kepada Tuhan untuk mengirimkan rasul karena kekosongan kenabian pula pada masa itu. Contoh lain pengaruh psikologis dalam penafsiran terdapat pada pembahasan mengenai QS [2]: 2830 ketika malaikat menanyakan kepada Allah mengapa harus menciptakan Adam sedangkan mereka melakukan kerusakan dan saling menumpahkan darah. Muh. Mahmud Hidjazi menekankan untuk tidak memahami itu sebagai kritik terhadap manusia melainkan murni sebuah ekespresi iri dari malaikat, karena merasa bahwa seharusnya merekalah yang menjadi nomor satu bukan manusia. Namun terkadang pendekatan psikologis juga dianggap menghilangkan nilai kemukjizatan. Misal jika pendekatan psikologis digunakan terhadap kisah orang yang tidur selama 100 tahun, ${ }^{76}$ menurut Qutb hal itu hanya akan mengarahkan pada pemaknaan bahwa yang terjadi hanyalah sugesti semata bukan benar-benar dihidupkan setelah tertidur selama 100 tahun. Sedangkan kisah tersebut adalah benar adanya. ${ }^{77}$

Selain makna psikologis, makna simbolis juga sering digunakan oleh para penafsir modernis dalam menafsirkan al-Qur'an. Misalnya penafsiran Muh. Rahim alDin terhadap QS [95]:1-3, mengartikan beberapa kata seperti tin, zaitun, sinin dan baladil amin sebagai tiga kota suci di mana Tuhan menurunkan nabi atau rasul dan tempat reformasi sosial. Di mana tin sebagai symbol gunung Sinai atau gunung Djudi, di mana Nuh bersyukur kepada Allah setelah sekian lama terombang-ambing di lautan. Kemudian zaitun menyimbolkan Zieta atau Syiria, di mana nabi Isa hidup. Lalu sinin mewakili Sinai nabi Musa. Dan terakhir baladil amin merupakan kota Mekkah, tempat diutusnya nabi Muhammad. Contoh lainnya adalah penafsiran Tantawi Djawhari yang bermazhab romantisme terhadap pemaknaan beberapa ayat-ayat yang dia kaitkan dengan perkembangan atau sejarah ketauhidan (monoteisme). Menurutnya perkembangan ketauhidan umat Islam terbagi menjadi tiga tahap yang dia kaitkan dengan ayat kursi, ayat mengenai perdebatan Ibrahim dan Namrud dan terakhir ayat mengenai kisah Uzair dan Keledainya. Pada ayat kursi yang penuh dengan glorifikasi dia mengaitkannya dengan masa pertama Muslim. Sedangkan kisah perdebatan nabi Ibrahim dan Namrud dia kaitkan dengan fase berikutnya yaitu munculnya sekte-sekte dalam Islam seperti Sunni, Syiah, Mu'tazilah dll. Dan yang terakhir kisah mengenai Uzair dan keledainya dia kaitkan dengan kebangkitan bangsa-bangsa dan munculnya para filusuf dan Ilmuan Muslim yang membangkitkan kembali Islam dengan menawarkan ilmu pengetahuan terhadap peradaban Muslim. ${ }^{78}$

Terakhir Baljon juga menunjukkan ada model penafsiran modern yang menggunakan pendekatan moralis. Penafsir mencoba menafsirkan ayat al-Qur'an dengan mengaitkannya dengan konteks kehancuran bangsa Islam ketika bangsa Barat justru maju. Misalnya penafsiran QS [2]:58-61 oleh Tantawi Djawhari, yang mengatakan bahwa kemewahan dan kerakusan akan menghancurkan sebuah bangsa sedangkan kesederhanaan dan nomadenisitas akan menguatkannya. Dia mencontohkan bagaimana kaum Hun dapat menguasai Romawi atau bangsa Arab yang mampu mengalahkan Persia. Dia juga mengaitkan itu dengan fenomena yang terjadi pada saat itu di mana Sultan Maroko membuat pesta yang megah ketika menikahkan anaknya berbanding terbalik dengan pesta pernikahan pangeran Belgia, Leopold, dengan putri

\footnotetext{
${ }^{76}$ Yang dimaksud di sini adalah kisah Nabi Uzair dan keledainya

${ }^{77}$ Baljon, Modern Muslim Koran Interpretation (1880-1960), 27-28.

${ }^{78}$ Baljon, Modern Muslim Koran Interpretation (1880-1960), 28-29. 
Swedia Astrid yang jsutru sederhana. Contoh penafsiran moralis lainnya adalah yang dilakukan oleh Ahmad al-Din mengenai tujuh dosa atau kejahatan yang menyebabkan manusia berbuat salah yaitu: kesedihan, keserakahan, keserakahan, kemalasan, kesombongan diri, takhayul dan pemberontakan. Menurutnya tujuh dosa dosa itu dapat disembuhkan dengan tujuh ayat surat al Fatihah QS [1]: 1-7. ${ }^{79}$

Dari berbagai jenis penafsiran modernis di atas Baljon mencatat bahwa model penafsiran al-Qur'an modernis memiliki banyak kesamaan dengan pemikiran para ilmuan di Barat. Namun hal itu terjadi tanpa berkaitan satu sama lain, bahwa para pemikir Islam modernis ini mendapatkan jalan pemikiran tersebut secara independen. $^{80}$

\section{Kesimpulan}

Dari pemaparan di atas penulis menyimpulkan setidaknya dua kesimpulan utama. Pertama, kategorisasi corak penafsiran berdasarkan jenisnya seperti sastra bahasa, penafsiran ilmiah, filsafat dan teologi, fikih atau hukum, tasawuf, sastra budaya kemasyarakatan, Ilmi, dan terakhir adabi Ijtimai tidak dapat terikat dengan periodesasi corak penafsiran karena beberapa corak di atas terkadang muncul baik dalam periode klasik pun periode modern. Dan sebaliknya juga kategorisasi berdasarkan periode pun tidak terikat dengan metode penafsiran apakah ia menggunakan riwayat (bil matsur) maupun dengan nalar (bil ra'yi), karena pada setiap periode baik klasik maupun modern terdapat kedua jenis metode tafsir tersebut.

Kedua, yang membedakan penafsiran modernis dari pendahulunya pada periode klasik adalah paradigma positivisme abad ke-19 yang mempengaruhi pemikiran Muslim, dan beberapa sarjana Muslim, khususnya dari India-Pakistan dan Mesir, berusaha menafsirkan ulang al-Qur'an secara berbeda dibandingkan dengan tren penafsiran klasik. Meskipun dapat dilihat bahwa di antara para penafsir modernis juga beberapa ada yang mengarah pada sekularisasi agama, ada juga di antara mereka yang cenderung relijius namun memahami al-Qur'an yang lebih tekstual.

${ }^{79}$ Baljon, Modern Muslim Koran Interpretation (1880-1960), 29-31.

${ }^{80}$ Baljon, Modern Muslim Koran Interpretation (1880-1960), 31.

277 | at-8urhan: Kajian Ilmu dan Pengembangan Budaya Al-Qur'an, Vol. 20, No. 2, Desember 2020: 263-280. 


\section{Daftar Pustaka}

AB, Zuherni. “Tafsir Isyari dalam Corak Penafsiran Ibnu 'Arabi.” Al-Mu'ashirah 13, no. 2 (Juli 2016): 131-43.

Abdul-Raof, Hussein. Schools of Qur'anic Exegesis: Genesis and Development. London; New York: Routledge, 2013.

al-Bayḍāwı. Anwār al-tanzıl wa-asra $r$ al-ta’wıl. Beirut: Dar Ehia Al-Tourath Al-Arabi, t.t.

al-Nasafı. Tafsır al-Nasafi- (Mada rik al-tanzıl wa $h^{-}$aqā’iq al-ta'wll). Istanbul: Kahraman Yay., 1984.

al-Qattan, Manna Khalil. Mabahiş fi 'Ulum Qur'an. Kairo: Maktabah Wahbah, t.t.

al-Qushayri. al-Risāla al-qushayriyya. Beirut: Al-maktaba Al-assrya, 2008.

al-Sulamı. Haqā’iq al-tafsı̄̄. Beirut: Dar Al-Kutub Al-Ilmiyya, 2004.

al-Suyūtı. al-Itqān fi Ulūm al-Qur'an. Riyadh: Mucamma' Al Malik Fahd Li Tibae Al Mushaf Al Shareef, t.t.

Asad, Talal. "The Idea of an Anthropology of Islam.” Qui Parle 17, no. 2 (2009): 1-30. https://doi.org/10.5250/quiparle.17.2.1.

Baljon, Johannes Marinus Simon. Modern Muslim Koran Interpretation (1880-1960). Leiden: E. J. Brill, 1968.

Calder, Norman. "Tafsir from Tabari to Ibn Kathir: Problems in the Description of a Genre, Illustrated with Reference to the Story of Abraham." Dalam Approaches to the Qur'an, disunting oleh G. R. Hawting dan AbdulKader A. Shareef, 101-139. London: Routledge, 1993.

Çoruh, Hakan. Modern Interpretation of the Qur'an: The Contribution of Bediuzzaman Said Nursi. Cham: Springer International Publishing, 2019. https://doi.org/10.1007/978-3-030-15349-6.

- _ - "Tradition, Reason, and Qur'anic Exegesis in the Modern Period: The Hermeneutics of Said Nursi." Islam and Christian-Muslim Relations 28, no. 1 (2 Januari 2017): 85-104. https://doi.org/10.108o/o9596410.2017.1280915.

Danial. "Corak Penafsiran Al-Qur'an Periode Klasik hingga Modern.” Hikmah XV, no. 2 (2019): 70-102.

Demirci, Muhsin. Tefsir Tarihi. Istanbul: IFAV, 2003.

Denffer, Ahmad von. 'Ulūm Al-Qur'ān: An Introduction to the Sciences of the Qur'ān. Leicester, U.K.: Islamic Foundation, 1994.

Dozan, Wely. "Analisis Pergeseran Shifting Paradigm Penafsiran: Studi Komparatif Tafsir Era Klasik dan Kontemporer." At-Tibyan: Jurnal Ilmu Alqur'an dan Tafsir 5, no. 1 (2020): 37-55. https://doi.org/10.32505/tibyan.v5i1.1631.

Gätje, Helmut. The Qur'an and Its Exegesis. Oxford: Oneworld Pub., 2008.

Gilliot, Claude. Exegesis of the Qur'àn: Classical and Medieval. Leiden-Boston: Brill, 2002.

Gilliot, Claude. “Traditional Disciplines of Qur'ānic Studies.” Dalam Encyclopaedia of the Qur'ān, disunting oleh Jane Dammen McAuliffe. Leiden-Boston: Brill, 2006.

Gusmian, Islah. Khazanah tafsir Indonesia: dari hermeneutika hingga ideologi. Cetakan I. Yogyakarta: Penerbit \& distribusi, LKiS Yogyakarta, 2013.

Hakim, Lukman. "Corak Feminisme Post-Modernis dalam Penafsiran Faqihuddin Abdul Kodir." Jurnal Studi Ilmu-Ilmu al-Qur'an dan Hadis 21, no. 1 (Januari 2020): 23153.

at-oburhan: Kajian Ilmu dan Pengembangan Budaya Al-Qur'an, Vol. 20, No. 2, Desember 2020: 263-280 | 278 
Hayy, Al-Farmawi Abdul. Metode Tafsir Maudhu'i Dan Cara Penerapannya. Diterjemahkan oleh Rosihan Anwar. Bandung: Pustaka Setia, 2002.

Ibn Kathır, Ab al-Feda. Tafsır al-Qur'a'n al-'Azım. Cairo: Maktabat Avlad Al Shaykh LetTurāth and Muassasat Qurtuba, 2000.

Iyyazi, Muhammad Ali. Al-Mufassirun; Hayatuhum wa Manhajatuhum. Teheran: 'Ulum al-Islamy, 1414.

Jawharı, Tantāwı. al-Jawāhir fı tafsı̄ $r$ al-Qur'a n al-karım. Egypt: Mustafa. Al-Bābı AlHalabi, 1350.

Krämer, Gudrun, dan Sabine Schmidtke, ed. Speaking for Islam: religious authorities in Muslim societies. Social, economic and political studies of the Middle East and Asia, v. 10o. Leiden ; Boston: Brill, 2006.

Kusroni. "Menelisik Sejarah dan Keberagaman Corak Penafsiran Al-Qur'an." ElFurqania 05, no. 02 (Agustus 2017): 132-46.

Laila, Izzatul. "Penafsiran Al-Qur'an Berbasis Ilmu Pengetahuan.” Epistemé: Jurnal Pengembangan Ilmu Keislaman 9, no. 1 (10 Juni 2014): 45-66. https://doi.org/10.21274/epis.2014.9.1.45-66.

Makin, Al. Keragaman dan perbedaan: Budaya dan Agama dalam Lintas Sejarah Manusia. Yogyakarta: Suka Press, 2016.

McAuliffe, Jane Dammen. Qur'ānic Christians: an Analysis of Classical and Modern Exegesis. Cambridge: Cambridge University Press, 2007.

Razi, Fakhr al-Dın. Mafātıh al-Ghayb. Beirut: Dar al-Fikr, 1981.

Riddell, Peter G. "Al-Baydawi." Dalam The Qur'an: an Encyclopedia, disunting oleh Oliver Leaman. London-New York: Routledge, 2006.

_—_. "Al-Tabari.” Dalam The Qur'an: an Encyclopedia, disunting oleh Oliver Leaman. London-New York: Routledge, 2006.

Rippin, Andrew. "Tafsir." Dalam The Encyclopaedia of Religion. New York: Macmillan, 1987.

Saeed, Abdullah. Interpreting the Qur'an: Towards a Contemporary Approach. 1 ed. Routledge, 2005. https://doi.org/10.4324/9780203016770.

Saeed, Abdullah. "Qur'an: Tradition of Scholarship And Interpretation.” Dalam Encyclopedia of Religion, disunting oleh Lindsay Jones. Detroit: Macmillan Reference, 2005.

Saeed, Abdullah. The Qur'an: An Introduction. New York: Routledge, 2009.

Shihab, M. Quraish, dan Ihsan Ali-Fauzi. "Membumikan” Al-Qur'an: fungsi dan peran wahyu dalam kehidupan masyarakat. Bandung: Mizan, 2002.

Sunarwoto, ed. Islam: Antara Teks, Kuasa dan Identitas. Yogyakarta: Arti Bumi Intaran, 2018.

Syarief, Ghilman Nursidin. "Metode dan Corak Penafsiran al-Qur'an” o1 (2019): 10.

TTabarı. Jāmi al-Bayān'an Ta’wıl Āy al-Qur'an. Cairo: Hacr, 2001.

Tanjung, Abdurrahman Rusli. "Analisis terhadap Corak Tafsir Al-Adaby Al-Ijtima'i." Analytica Islamica 3, no. 1 (2014): 162-88.

Wartini, Atik. "Corak Penafsiran M.Quraish Shihab dalam Tafsir Al-Misbah.” HUNAFA: Jurnal Studia Islamika 11, no. $1 \quad$ (19 Juni 2014): 109-26. https://doi.org/10.24239/jsi.v11i1.343.109-126.

Wielandt, Rotraud. “Exegesis of the Qur'ān: Early Modern and Contemporary.” Dalam Encyclopaedia of the Qur'ān, disunting oleh Jane Dammen McAuliffe. LeidenBoston: Brill, 2002.

279 | at-\$urhan: Kajian Ilmu dan Pengembangan Budaya Al-Qur'an, Vol. 20, No. 2, Desember 2020: 263-280. 
Muhamad Ibtissam Han \& Topikurohman

Zamakhshari. al-Kashshaf an Haqaiq al-Tanzil. Beirut: Dar al-Marifah, t.t.

al-هurhan: Kajian Ilmu dan Pengembangan Budaya Al-Qur'an, Vol. 20, No. 2, Desember 2020: 263-280 | 280 